\title{
Development of Local Content Learning Module for Karawo Embroidery Crafts in Vocational High Schools in Gorontalo
}

\author{
Sapia Husain Abdul Haris Panai Nurhayati Abbas Hamzah B. Uno \\ Postgraduate Doctoral Program of Education, State University of Gorontalo
}

\begin{abstract}
The research problem was based on the fact that local content learning had not been optimally implemented. In the learning outcomes, the sulwo karawo skills were still low. Learning carried out was only limited to knowledge transfer. The effort taken to overcome this problem was to develop a karawo learning module. This study aims to: (1) Describe objective conditions of local content embroidery module in vocational high schools in Gorontalo, (2) Describe the conceptual learning model of the local content of karawo embroidery modules in vocational high schools in Gorontalo, (3) Describe the implementation of local content embroidery in vocational high schools in Gorontalo, (4) Describe the effectiveness of the local content karaman embroidery module in vocational high schools in Gorontalo. The approach used was a combination of qualitative and quantitative approaches. The method used was the research and development ( $\mathrm{R} \& \mathrm{D})$ method. The research findings showed that: (1) Development of local content learning module for karawo embroidery craft in vocational high schools in Gorontalo was conducted by using a research and development approach known as Research and Development (R \& D) referring to the ADDIE model development model consisting of: 1) analyze, (2) design, (3) development, (4) implementation, and (5) evaluation; (2) Feasibility test of the local content learning of Karawo embroidery craft in vocational high schools in Gorontalo obtained average module validation rates by material experts and media experts that were 94.99 with a very feasible category and 90.37 with very feasible category respectively. Additionally, teacher module validation average was 96.43 or very feasible and evaluation by participants student was 92 or very feasible; (3) After the local content learning module for karawo embroidery craft had given to students in vocational high schools in Gorontalo, effectiveness of student learning outcome achievement had increased significantly, indicated by the acquisition of Zscore of $2.28>$ Ztable $=0.85$. The findings also indicated that the Karawo embroidery learning module could improve student learning outcomes, hence it is recommended to relevant parties to use the module to improve student learning outcomes.
\end{abstract}

Keywords: Local Content Learning Module for Karawo Embroidery Craft for Vocational School Students

DOI: $10.7176 / \mathrm{JEP} / 10-15-09$

Publication date:May $31^{\text {st }} 2019$

\section{Introduction}

\subsection{Research Background}

Vocational schools are high school educational level prioritizing student skill development. The skills are obtained by learning in either schools or industries. Industry plays an important role for learning process in vocational schools by cooperating with the schools in industry practice implementation. Meanwhile, students shall conduct such practice to implement knowledge they have obtained during school. Students may get new knowledge in industry, as learning in a real work condition and situation. After finishing the practice, students will be busy by various final activities.

Local content learning activities are designed to give students knowledge, skills, and behaviors, and thus providing them adequate knowledge about social demand and environment according to applicable local rules that sustain both local and national development.

The activity is a curricular activity aiming to develop competence accustomed to local characteristics, potentials, and developmental prospect, but the material cannot be categorized into any existing subject study. A series of learning activities that has been set by the school and school committee are then included in the local content study subject.

One of the local contents integrated into a subject study is karawo embroidery. The learning uses the same learning models as that of other study subjects. The subject study is a model oriented to process uses to reveal and figure out facts and concepts as well as develop behaviors and values. Learning process using this approach is started by observing a real object with hands-on experiences, so that students are asked to have more scientific learning activities. They shall be accustomed to do direct observations, ask, reason, present, conclude, and communicate by themselves.

Unfortunately, vocational high schools in Gorontalo did not provide any appropriate local content module for karawo embroidery. There were only five modules at school, making the local content learning not optimal. Additionally, the content was not applicable, as only containing summaries of karawo embroidery information.

According to the implication of local content curriculum for teaching learning process that is in accordance with the Regulation of the Ministry of Education and Culture Number 22 Year 2006, school shall prepare and 
regulate learning procedures involving students by: (a) creating a conducive condition for learning, (b) creating a planning mechanism that provides feedbacks, (c) diagnosing learning demand, (e) formulating satisfying learning goals, (e) constructing necessary learning experience, and (f) evaluating learning achievements further.

To enhance local content skills, the learning model shall be developed based on students' local condition or environment and thus enables them to master the skills. In this term, learning material substances rely on the results of local potential analysis and shall be implemented in accordance with the students' development level, increasing their learning interests and motivation. By such learning model, students are expected to improve their skills.

The aforementioned explanation clarifies that learning by scientific learning model shall be directly implemented to learning process. Unfortunately, the learning process still used conventional methods and did not implement any scientific approach, restricting students to improve their skills and behaviors related with local content. Generally, students did not make achievement after joining the learning process, even their entrepreneur behaviors did not even increase. Therefore, scientific approach is one of the models that shall be concern for local content learning, especially for vocational high school students.

Recent learning by vocational high schools was still conventional. The learning still used lecturing and askanswer methods without any concern to increase students' competence and creativity in karawo embroidery learning. Besides, teachers could not implement good planning to enable students to learn karawo embroidery local content due to unavailable karawo embroidery materials at school.

Media used were also still conventional: they still used certain media that could not be accessed by students during learning process. Furthermore, there was no tools for practice available, giving little knowledge and few skills to students. Therefore, teaching material development in the form of module is important.

Karawo embroidery module shall be developed. The module shall contain learning materials that are only designed to enhance their skills, but also designed to improve their behaviors, competence, and work experience. The module shall also be develop to preserve and develop the artistic and economic local cultures and give opportunities for students to carry out a self-study.

The curriculum made was "Development of Local Content Learning Module for Karawo Embroidery Crafts in Vocational High Schools in Gorontalo". The development shall improve students' knowledge, behaviors, and skills, as well as productivity.

\subsection{Research Problems}

According to the research background, the research problems are:

1. What is the objective condition of local content learning module for karawo embroidery in vocational high schools in Gorontalo?

2. What is the conceptual model of local content learning module for karawo embroidery in vocational high schools in Gorontalo?

3. What is the implementation of learning module for karawo embroidery in vocational high schools in Gorontalo?

4. What is the effectiveness of local content learning module for karawo embroidery in vocational high schools in Gorontalo?

\subsection{Research Objectives}

Based on the research problems, the research generally aims to develop a local content learning module for karawo embroidery in SMK Provinsi Gorontal and to:

1. Describe the objective condition of local content learning module for karawo embroidery in vocational high schools in Gorontalo.

2. Describe the conceptual model of local content learning module for karawo embroidery in vocational high schools in Gorontalo.

3. Describe the implementation of learning module for karawo embroidery in vocational high schools in Gorontalo.

4. Describe the effectiveness of local content learning module for karawo embroidery in vocational high schools in Gorontalo.

\section{Theoretical Studies}

\subsection{Development of Local Content Module for Karawo Embroidery}

\subsubsection{Definition of Development}

Seels and Richey (Sumarno, 2012:54) argue that development is a process where we translate or describe a design specification into a physical figure. Development has a special meaning that is a process to produce learning materials. In addition to that, Tessmer and Richey (Sumarno, 2012:55) believe that development shall not only focus on demand analysis, but also other issues about preliminary-final analyses; such as contextual analysis. The development aims to result in products according to research findings. 
Hierarchically, development is an educational effort, either formal or informal that is implemented with a conscious, planned, directed, regulated, and responsible way to introduce, grow, and assist a personality that is balanced, whole, harmonious, and skillful according to his/her skills, intention, and capabilities as his/her own provision to add, improve, and develop to create optimum capabilities and independent individuals (Wiryokusumo, 2011:109).

Development research model applied in this research was ADDIE. Although each research and development model design had both weaknesses and strengths, ADDIE is more systematical and easily employed in a development research design. Therefore, we took ADDIE as our research and development design model.

\subsubsection{Module}

Module is "a set of learning materials systematically presented, hence enables students to study with or without any facilitator or teacher" (Ministry of National Education, 2008:20). Additionally, module is also a learning material for self-study, as containing self-study instructions. Readers can study outside the school without any facilitator, so that module is also frequently called a self-instructional material.

Module is a learning facility or instrument containing materials, methods, restrictions, and methods to evaluate. The materials are systematically designed as interesting as possible, enabling students to achieve expected competencies.

In learning development research, indicators to clarify that model is effective are: (1) students' learning outputs and (2) students' activities. In this development research, we measured module's effectiveness based on students' learning outputs. The outputs were obtained from examination carried out in the end of learning session using the module.

\subsubsection{Local Content}

Local content, as intended in the Elucidation of the Law Number 20 Year 2003 on National Education System is a study material to build students' understanding about their local area potentials. The Government Regulation Number 32 Year 2013 Article 77N on Amendment to the Government Regulation Number 19 Year 2005 on National Standards conveys that (1) Local content for all education units shall contain learning process and content about local uniqueness and potentials, and (2) Local content shall be developed and implemented by all education units.

As a study material that build understanding about local area potentials, local content is necessary to improve students' behaviors, knowledge, and skills. As the result, they will (1) know and be close to their natural, social, and cultural environments, (2) hold capabilities, skills, and knowledge about their local area that are useful for themselves and the society, and (3) have behaviors and attitudes in accordance with applicable values/regulations to preserve and develop the values/regulations to sustain national development.

\subsubsection{Karawo Embroidery Craft}

a. Karawo Embroidery

Kerawang embroidery, initially known as karawo means embroidery by hands. The craft had developed in Gorontalo since the $17^{\text {th }}$ Century, during the Dutch colonialization. Nowadays, it has become the uniqueness of Gorontalo, even it is frequently sown into uniforms by several companies, government instances, or pilgrims from Gorontalo (http://www.mokarawo).

Karawo is one of the transparent embroider applied on a piece of cloth by using plain or colorful strings. It is commonly aimed to decorate certain parts of the cloth, making it more beautiful and interesting. Initially, it only used very primitive tools, but it can develop and survive until today (Husain, 2009:9).

\section{b. History of Karawo}

Based on its history, karawo existed in Gorontalo since the Dutch colonization, or in 1713. Although only using primitive tools, but surprisingly, it can develop and survive until today. The initial use of karawo embroidery was to add small details on short pants or necklines, but today, it has been greatly developed, either in its design patterns or materials (Husain, 2010:9).

Tied karawo had been generated by Gorontalo ancestors since 1713 and was created by the native Gorontalo people, Ayula people. Besides, there is also kerrawang manila from the Phillipines, Sangihe Islands, Thalaud that were then brought to Gorontalo (Husain, 2009:9).

\section{c. Textile Materials}

There are various types of cloth that is usually classified in accordance with the trademark or making techniques. Trademark is affected by some factors; such as weaving originality, name of the producing company, model, function, use, and others. Naming referring to making techniques is more frequently done, because implying the cloth characteristics.

We had classified cloth according to its functions. We covered various clothe, from that used for garments, or that used for non-garments and other necessities.

The functions are categorized into four, i.e. 1) Apparel function, 2) Household function, 3) Industrial function, and 4) Cultural/traditional function. 


\section{d. Karawo Design}

Design is an English word that means a plan. From the word, we derived our own word, desain that means to create or think. If design is a noun, it is a design containing structures of lines, shapes, sizes, colors, textures, and values of a certain item made by design principles. Furthermore, if it is a verb, design is a shape planning process aiming to give functions to the designed items after they are decorated.

Design is a pattern that becomes the base to make a certain item as cloths. Design is resulted through thinking, consideration, and calculation social preference that is then drawn. Design shall be easily read or understood by others, so it is easy to implement the design.

\subsubsection{Entrepreneurship}

Riyanti (2003:5-7) confirms that entrepreneurship is an individual capability to determine and evaluate business opportunities by managing available resources. Therefore, entrepreneurship is actually close to human. Human is the primary creature and the central point of social civilization development. In accordance to the idea, there are four elements that shall be paid attention to comprehend entrepreneurship philosophy or hierarchy, namely (1) Human existence hierarchy is workers. Without works, their function as the primary creature will extinct, (2) Human life obligation is to work. By working, they create things to give meaning to their life and civilization, since human works to survive and sustain their life. By working, their life will also be full of spirit, dynamic, and joyful, hence emphasizing their existence, (3) Working ethics are one of the inner dynamic factors. By working ethics, human can produce things. There are two variables measuring working outputs that are (1) Use and (2) Productivity, and (4) Life demand shall be fulfilled by human to survive.

Sembel (2007:43) argues that individuals with entrepreneur spirit shall commonly have these prominent characteristics, i.e. (1) willing to take a risk, (2) optimistic, (3) pioneering, (4) forward-thinking, (5) energetic, (6) aware of time, facilities, strategies, and locations.

Furthermore, achieved entrepreneurs are commonly identified by these following characteristics (Suryana, 2006:33-34): (1) Problem-solving, (2) Feed-back oriented to investigate both success and failures, (3) Highly responsible, (4) Willing to take a risk, and (5) Challenging. Entrepreneurs are challenge-addicted, but they are also good at avoiding the most difficult challenge that may give them the least profit.

\subsubsection{Theoretical Framework}

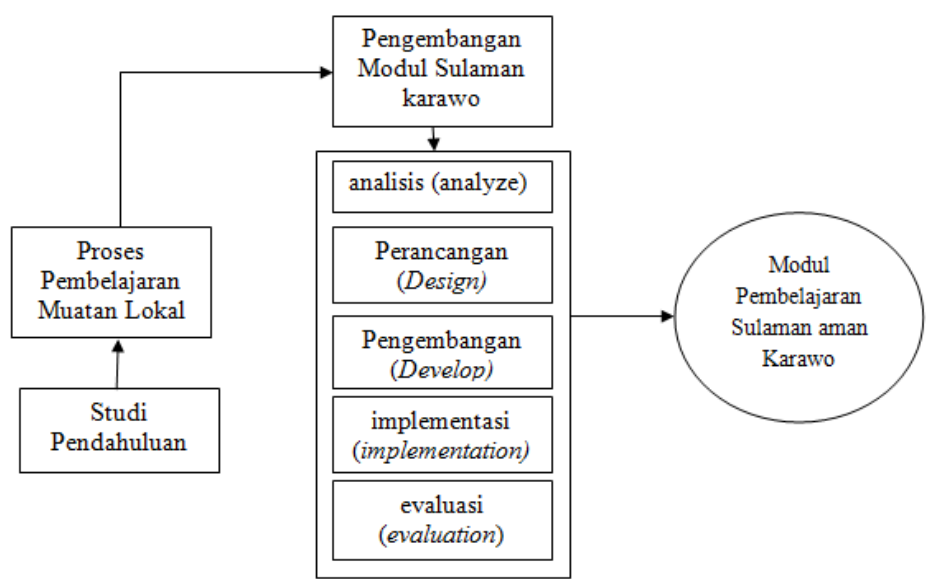

Notes:

Pengembangan modul sulaman karawo

Karawo embroidery module development

Proses pembelajaran muatan lokal

Studi pendahuluan

Modul pempelajaran sulaman karawo

Local content learning process

Introduction study

Karawo embroidery learning module

\section{Research Methods}

\subsection{Research Time and Location}

The research was conducted at state vocational high school in Gorontalo during odd semester the year of 2018/2019 in July-December 2018.

\subsection{Research Method and Approach}

Method used in this research was research and development (R \& D) method. The method aimed to produce a certain product and examine the product effectiveness. A good product should fulfill these following quality aspects, namely (1) validity, (2) practicality, and (3) effectiveness (Sugiyono, 2011:297). Product resulted by this research was a module. The module effectiveness was assessed to analyze both its validity and practicality as a module. After confirmed as valid, students were allowed to look through and conveyed their judgment. Module 
that had been confirmed as valid, practical, and effective could be properly stated as a module that could be used in learning process.

\subsection{Research Procedure}

1. Research Stage I

2. Research Stage II

3. Module Validation

4. Module Revision

5. Module Trial

\section{4. $\quad$ Experiment Subject}

Experiment subjects of this research were:

(1) 25 XII-graders of SMK Negeri 2 Gorontalo. For the module trial activity, we employed 15 students of SMK Negeri 4 Gorontalo.

(2) Five local content teachers of SMK Negeri 2 and SMK Negeri 4 Gorontalo.

\subsection{Types of Data}

Data were defined as information about a certain matter. It came in forms of known matter, assumption, or fact described by numbers, symbols, codes, and others. There were two types of data to develop the module that were qualitative and quantitative data.

\subsection{Data Collection Instrument}

Data collection instrument was the method or tool used by a researcher to collect data. Data collected were accurate and in accordance with the fact, when instrument used by the researchers were correct, appropriate, and valid. As there were many instruments available, we should select an instrument suitable for the research and development method. The instruments were interview, questionnaire, and test.

\subsection{Data Analysis Technique}

Data analysis was a process to systematically investigate and compile data obtained by interviews, field observations, and test. The data were organized in forms of statistic data. After that, conclusion might be drawn to make the findings understandable for the researcher and others. Data analysis technique for this research was by collecting data by employing the instruments. Next, the data were processed according to the research and development procedure. Data analyzed in the karawo embroidery module development were quantitative data.

Data analysis technique applied to analyze data gathered from the results of validity assessment was by calculating the mean of the results of student questionnaire and evaluation. The score was obtained by this following assessment formulae:

$$
\text { Final score }=\frac{\text { Obtained score }}{\text { Total score }} X 100
$$

To emphasize the data of validity assessment result, level of validity criteria qualification was then created. The criteria contained scores 1-4. Score 1 was the lowest score; while score 4 was the highest. Scale range in the assessment criteria were figured out by the highest score range was reduced by the lowest score and divided by the highest score. The criteria are presented in Table 3.1.

Table 3.1 Criteria of Product Revision and Validity Level

\begin{tabular}{|l|c|l|}
\hline No. & Criteria & \multicolumn{1}{c|}{ Validation Level } \\
\hline 1. & $75.01 \%-100.00 \%$ & Very valid (may be used without any revision \\
\hline 2. & $50.01 \%-75.00 \%$ & Valid enough (may be used, but with a few revisions \\
\hline 3. & $25.01 \%-50.00 \%$ & Invalid (shall not be used) \\
\hline 4. & $00.00 \%-25.00 \%$ & Very invalid (forbidden to use) \\
\hline
\end{tabular}

\section{Findings and Discussion}

\subsection{Research Findings}

4.1.1. Objective Condition of Local Content Learning Module for Karawo Embroidery in Vocational High Schools in Gorontalo

Objective condition of local content module was customized to the second step of ADDIE (Analysis, Design, Development, Implementation, and Evaluation) learning system design model. The first step was to determine student learning goals in cognitive, psychomotor, and affective fields. It aimed to enhance learning outputs. The second step was to arrange a test. The test should be based on the learning goals. The test was conducting by holding a formative test in the end of each learning activity. Furthermore, the final test was conducting by giving students multiple choice questions. The third step was to determine proper learning strategies by applying the 
discussion method. In this step, students were allowed to propose their arguments about karawo. The fourth step was to create a module design. Additionally, module developed was a local content module including the module cover, forewords, table of contents, list of tables, list of figures, and local content learning materials. The module should also contain guiding questions, karawo concept, glossary, and references. The module should be designed as interesting as possible for students to study local content.

\subsubsection{Conceptual Model of the Local Content Learning Module for Karawo Embroidery in Vocational} High Schools in Gorontalo

1) Procedures of Learning Module Development for Karawo Embroidery Validation results by the material experts are shown in the following table.

\begin{tabular}{|c|c|c|c|c|}
\hline No. & Component & Score & Percentage & Category \\
\hline $\mathbf{A}$ & \multicolumn{4}{|l|}{ Content Validity } \\
\hline 1. & Material suitability with core competences and basic competences & 12 & 100.00 & Very valid \\
\hline 2. & Material accuracy & 12 & 83.38 & Valid \\
\hline 3. & Learning material facilities & 22 & 91.67 & Very valid \\
\hline 4. & Material modernity & 13 & 86.67 & Valid \\
\hline B & \multicolumn{4}{|l|}{ Presentation Validity } \\
\hline 1. & Presentation technique & 7 & 87.50 & Valid \\
\hline 2. & Presentation facilities & 31 & 96.88 & Very valid \\
\hline 3. & Learning presentation & 4 & 100.00 & Very valid \\
\hline 4. & Presentation completeness & 9 & 75.00 & Valid \\
\hline $\mathbf{C}$ & \multicolumn{4}{|l|}{ Language Assessment } \\
\hline 1. & Clarity & 10 & 83.33 & Valid \\
\hline 2. & Communicativeness & 7 & 87.50 & Valid \\
\hline 3. & Interactive language & 7 & 87.50 & Valid \\
\hline 4. & Suitability with student development level & 7 & 87.50 & Valid \\
\hline 5. & Sequential and integrated mindset & 7 & 87.50 & Valid \\
\hline 6. & Terminology & 6 & 75.00 & Valid \\
\hline D & \multicolumn{4}{|l|}{ Curriculum Assessment } \\
\hline 1. & Approach characteristics & 18 & 90.00 & Very valid \\
\hline 2. & 2013 Curriculum principles & 10 & 83.33 & Valid \\
\hline \multicolumn{3}{|c|}{ Mean } & 87.73 & Valid \\
\hline
\end{tabular}

Referring to the recapitulation results by the material experts, there were four indicators assessed. In the content validity, there were four indicators: two of them were very valid and the two others were valid. In the layout validity, there were four indicators as well: two of them were very valid and the two others were valid. Meanwhile, in the language assessment, there were six indicators that were entirely valid. Eventually, in the curriculum assessment, there were two indicators: one indicator was very valid and the other one was valid.

Validation results by the material experts on the module for karawo embroidery are presented in the following table.

\begin{tabular}{|c|l|c|c|c|}
\hline No. & Component & Score & Percentage & Category \\
\hline 1. & Module size & 7 & 87.50 & Valid \\
\hline 2. & Module cover design & 31 & 86.11 & Valid \\
\hline \multicolumn{2}{|c|}{ Mean } & $\mathbf{7 7 . 0 4}$ & Valid \\
\hline
\end{tabular}

Referring to the recapitulation results, there were three indicators assessed that were entirely valid, so there would be no revision. The score was 77.04.

Module validation recapitulation by the teacher is as follows:

\begin{tabular}{|c|l|c|c|c|}
\hline No. & Component & Score & Percentage & Category \\
\hline 1. & Before learning & 25 & 89.29 & Valid \\
\hline 2. & After learning & 26 & 92.86 & Very valid \\
\hline \multicolumn{2}{|c|}{ Mean } & $\mathbf{9 1 . 0 7}$ & Very valid \\
\hline
\end{tabular}

According to the results of assessment recapitulation by the teacher, there was one valid indicator and one very valid component with the final score of 91.07. Therefore, it was very valid and thus did not need any revision.

Then, students' assessment on the learning module for karawo containing 25 questionnaire items revealed that there were 14 very valid items and seven valid items.

\section{2) Effectiveness of Model Development}

\section{(1) Trial Stage 1}

Evaluation was given in the end of the learning by post-test to observe students' knowledge. Instrument used was test. 
The test results stated that the minimum pre-test score for the knowledge aspect was 28; while the maximum one was 35. Moreover, the minimum and maximum post-test score was 30 and 38 respectively. The mean and standard deviation of pre-test score were 31.4 and 1.89 respectively; while the mean and standard deviation of post-test score were 34.12 and 2.32 .

With the significance level of $95 \%(\alpha=0.05$, two-party test $)$ and $n=25, Z_{\text {table }(1-1 / 2 \alpha)}=Z_{0.975}=0.85$. The test criteria was as follows. $\mathrm{H}_{0}$ was accepted if $-\mathrm{Z}_{\text {table }}<\mathrm{Z}_{\text {count }}<\mathrm{Z}_{\text {table }}$ and unaccepted if other events took place. Becuse $\mathrm{Z}_{\text {count }}=2.28>\mathrm{Z}_{\text {table }}=0.85, \mathrm{H}_{0}$ was unaccepted, clarifying that there was a significant difference between pre-test and post-test about the knowledge aspect.

(2) Trial Stage II

The test results suggested that the minimum and maximum pre-test score for the knowledge aspect were 28 and 36 respectively. Meanwhile, the minimum and maximum post-test score was 30 and 39 respectively. The mean and standard deviation of pre-test score were 31.72 and 1.79 respectively; whereas the mean and standard deviation of post-test score were 35.08 and 2.08 .

With the significance level of $95 \%(\alpha=0.05$, two-party test $)$ and $n=25, Z_{\text {table(1-1/2 } \alpha)}=Z_{0.975}=0.85$. The test criteria was as follows. $\mathrm{H}_{0}$ was accepted if $-\mathrm{Z}_{\text {table }}<\mathrm{Z}_{\text {count }}<\mathrm{Z}_{\text {table }}$ and unaccepted if other events happened. Since $Z_{\text {count }}=2.28>Z_{\text {table }}=0.85, \mathrm{H}_{0}$ was unaccepted, confirming that there was a significant difference between pre-test and post-test about the knowledge aspect.

\subsection{Discussion}

We elaborated the findings as follows:

1. Objective Condition of Local Content Learning Module for Karawo Embroidery in Vocational High Schools in Gorontalo

Module used in learning activities in vocational high schools in Gorontalo was divided into three parts: praintroductory session, introduction, and content whose description is as follows:

a) Pre-introductory Session

a) Cover containing the material title, karawo, applied curriculum, module target, pictures or illustrations, module compiling team, supervisor, and instance.

b) Background containing the background of module development and forewords.

c) Module manuals containing standard competences, basic competences, indicators, discussion, and Learning Cycle 5-E steps.

d) Table of contents containing sub-titles and sub-sub-titles as well as the page.

\section{b) Introduction}

The session covered standard competences, basic competences, learning output indicators, and several questions or discussions assisting students.

c) Content

The session consisted of karawo materials and learning activity steps, questions, feedbacks, glossary, and references. The learning activity steps are as follows:

a) Exploration

It aimed to group students and facilitated them to solve problems.

b) Explanation

It aimed to enable students to explain the learning topic by their own understanding.

c) Elaboration

It aimed to make students able to apply their findings on a subject matter.

d) Evaluation

It contained problems to investigate students' capability on material mastery.

e) Key Answers

It contained answers of the problems given. The key answers aimed to help students know the correct answers of problems given.

f) Glossary

It contained terminologies in the module. Glossary was necessary to ease students when they were looking up any foreign terminologies.

g) References

It contained references used to develop the module for karawo.

The entire module frameworks were developed by completing, improving, and adding several important items to perfect the module.

2. Conceptual Model of Local Content Learning Module for Karawo Embroidery in Vocational High

Schools in Gorontalo

a. Framework for Module Development

Learning module for karawo in vocational high schools in Gorontalo was developed as follows: 
a) Pre-introductory Session

i. Cover containing the material title, karawo; used curriculum; module targets, pictures or illustrations; module compiling team; supervisor; and instance.

ii. Table of content containing sub-title and sub-sub-title as well as the page.

iii. List of table containing sub-title and sub-sub-title as well as the page.

iv. List of pictures containing sub-title and sub-sub-title as well as the page.

b) Introduction

Introduction including description, conditions, module manuals, core competences, basic competences, learning output indicators, and learning goals to assist students.

c) Content

Content involved karawo materials, summary, formative test, evaluation, closing, and references.

\section{i. Learning Material}

The learning material described all concepts and facts occurring related with the learning material itself, i.e. karawo.

\section{ii. Summary}

Summary contains materials learned by students in brief. The summary was written in a direct and understandable language.

iii. Formative Test

Formative test contained questions in forms of essay provided by students to examine their understanding about the learning material. Key answers were provided.

iv. Evaluation

v. Closing

It contained material questions to investigate students' material mastery.

vi. References

It contained a general conclusion and expectation about students' competence achievement.

\section{b. Test by Experts on the Karawo Learning Module}

\section{a) Material experts}

The development research aimed to create a valid product, karawo learning module according to several assessments by a material experts, media expert, teacher, and students. Assessment by the material experts was conducted by investigating the components of content validity, presentation validity, language assessment, and 2013 Curriculum assessment. Furthermore, assessment by the media expert was done by observing the component of graphics/layout covering the module size, cover design, and content design. Assessment by the teacher was performed by investigating the components of before and after the module was used. Assessment by students was conducted by observing the module layout, materials, and use.

There were 56 questions in the research questionnaire used by the material experts to validate the module. Those 56 questions were divided into some validity aspects. Content, presentation validity, language, 2013 Curriculum were assessed by 21, 14, 13, and eight questions respectively. Maximum ideal score was 224; while the minimum one was 56.

Based on assessment by the material experts in Table 4.5, the initial score of karawo learning module was 87.73. The score was valid, so that it was unnecessary to revise the module.

\section{b) Media Expert}

There were 31 questions in the questionnaire used by the media expert to validate the module. The questions were divided into several aspects. There were two, nine, and 20 questions for the module size, cover design, and content aspects respectively. Maximum ideal score was 124; whereas the minimum one was 31 .

In accordance with the assessment done by the media expert in Table 4.7, initial score of karawo learning module was 77.04. Referring to the validity criteria table, the score was then "valid with no revision".

\section{c) Teacher Assessment}

There were 14 questions in the research questionnaire used by the teacher to validate the module. Those 14 questions were divided into two validity aspects, i.e. before learning (seven questions) and after learning (seven questions). Maximum ideal score was 48; while the minimum one was 14.

Referring to assessment by the teacher in Table 4.9, the initial score of karawo learning module was 91.07. The score was "valid, with no revision".

\section{d) Student Assessment}

There were 25 questions in the questionnaire used by students to validate the module. The questions were divided into several aspects. There were six, 13, and six questions for the module layout, material presentation, and usability aspects respectively. Maximum ideal score was 100; whereas the minimum one was 25.

In accordance with the assessment conducted by students in Table 4.10, initial score of karawo learning module was 89 . Referring to the validity criteria table, the score was then "valid with no revision". 


\section{c. Product}

Trial Stage I to develop karawo learning module had been completed. The research aimed to produce a valid product according to assessments by the material experts, media expert, teacher, and students. Assessment by the material experts was performed to the aspects of content/material validity, presentation validity, language validity, and approach (2013 Curriculum). Assessment by the media expert was conducted to the graphic aspects including the module size, cover design, and content design. Assessment by the teacher was done to the aspects of before and after the learning was performed. Finally, assessment by student was conducted to the aspects of layout, material presentation, and usability.

There were three research stages that should be fulfilled, namely define, design, and develop. The final development product was a valid karawo learning module based on assessments by the material experts, media expert, teacher, and students. The development research was in accordance with the 4-D model. In the development stage, there were several revisions. First, the module draft I was validated by both material experts and media expert. Then, the draft was revised and analyzed to result in the module draft II. The revisions were in forms of advice/suggestions by both experts. After that, the draft was validated by the teacher, revised, and analyzed to create the module draft III. Next, the draft was tested in a learning process and revised to produce the master karawo learning module.

The first revision stage was conducted by both experts (material experts and media expert) and generated the module draft II. Revision was done to the module draft I (the module before validation). The revision produced a valid product after validation was given in accordance with suggestions. Then, the module was delivered to both material experts and media expert to obtain further validation. In this stage, there were some advice by the material experts that were:

a. Material addition to certain basic competences referring to local characteristics.

b. Reduction to summary content, since the content was too long.

c. Material presentation by showing more interesting pictures and providing the picture description. Pictures of karawo embroidery process should be clear and in details, so that students might follow the steps well and easily. The pictures should also be laid well to present the karawo characteristics. Another pictures should also be clear and well and orderly laid according to the orders of karawo embroidery work.

d. Simplification to the module front page or cover by inserting pictures representing each material. Interesting module cover was an attempt to draw students' interest and motivation to use the karawo embroidery learning module as one of their learning sources to improve their knowledge and skills.

e. The use of standard Indonesia language. Foreign and local words and sentences should be written in an italic font to ease students to understand the module content. Consistency in the use of certain fonts was important too. The suggested font was Arial 12. The font was well read and set.

f. Consistency in the module content order, implying that each module should come with the same order and be completed by terminology guidance. If finding any foreign words and sentences, students might give explanation on footnotes.

d. Implementation of Local Content Learning Module for Karawo Embroidery in Vocational High Schools in Gorontalo

Implementation of karawo learning module was performed in SMK Negeri 1 Gorontalo as the experimental class and SMK Negeri 2 Gorontalo as the control class. The implementation, or trial stage II was held to implement the revised learning modul.

\section{a. Expert Tests to the Karawo Learning Module \\ i. Material Experts}

Material experts in the trial stage I were Dr. Asni Ilham, M.Pd and Dr. Rustam I. Husain, S.Ag., M.Pd. Assessment by material experts was carried out by observing graphic/layout components involving the module size, cover design, and content design. Teacher assessment was conducted by investigating the components of before and after the module was used. Student assessment was done by observing the module layout, material presentation, and use.

There were 56 questions in the research questionnaire used by the material experts to validate the module. Those 56 questions were divided into some validity aspects. Content, presentation validity, language, 2013 Curriculum were assessed by 21, 14, 13, and eight questions respectively. Maximum ideal score was 224; while the minimum one was 56.

Based on assessment by the material experts in Table 4.5, the initial score of karawo learning module was 87.73. The score was "valid, with no revision".

\section{ii. Media Expert}

There were 31 questions in the questionnaire used by the media expert to validate the module. The questions were divided into several aspects. There were two, nine, and 20 questions for the module size, cover design, and content aspects respectively. Maximum ideal score was 124; whereas the minimum one was 31.

In accordance with the assessment done by the media expert in Table 4.7, initial score of karawo learning 
module was 77.04. Referring to the validity criteria table, the score was then "valid, with no revision".

\section{iii. Teacher Assessment}

There were 14 questions in the research questionnaire used by the teacher to validate the module. Those 14 questions were divided into two validity aspects, i.e. before learning (seven questions) and after learning (seven questions). Maximum ideal score was 48; while the minimum one was 14.

Referring to assessment by the teacher in Table 4.9, the initial score of karawo learning module was 91.07. The score was "valid, with no revision".

\section{iv. Student Assessment}

There were 25 questions in the questionnaire used by students to validate the module. The questions were divided into several aspects. There were six, 13, and six questions for the module layout, material presentation, and usability aspects respectively. Maximum ideal score was 100; whereas the minimum one was 25 .

In accordance with the assessment conducted by students in Table 4.10, initial score of karawo learning module was 89 . Referring to the validity criteria table, the score was then "valid with no revision".

\section{e. Product Revision}

There were three research stages, i.e. define, design, and develop. The final development product was a valid karawo learning module according to assessments by material experts, media expert, teacher, and students.

The second revision stage was revision conducted by experts (material experts and media expert) creating the module draft III. Revision was carried out to the module draft II (the module after the validation stage I). The revision generated a valid product to be used. After that, the module draft II was given to material experts and media expert to gain further validation. There were several revision from material experts, namely: 1) Word combination and separation should be reviewed, 2) Layout should be reviewed, and 3) Picture size should be customized. The third revision stage was revision to the product developed during trial stage by students. Revision were done to several module parts getting bad responses. The third revision stage covered: 1) Revision of the module back cover and 2) Revision of spaces.

There were still several weaknesses found in the karawo learning module that were 1) Material development was still limited to certain basic competences and 2) Development of karawo learning module was still limited for two vocational high schools only.

To examine the developed module effectiveness, we performed analyses of learning outputs in forms of pretest and post-test given to students during the trial stage I and II. The analyses are as follows.

\section{1) Trial Stage I}

Evaluation stage was carried out in the end of the learning by providing post-test to students. The post-test was given to investigate students' knowledge. Instrument used was test. The results of pre-test and post-test evaluation during the trial stage I were as follows: the minimum and maximum pre-test scores were 28 and 35 respectively, minimum and maximum post-test scores were 30 and 38 respectively, mean and standard deviation of pre-test scores were 31.4 and 1.89 respectively, and that of post-test scores were 34.12 and 2.32 respectively. In accordance with the test result to the difference between two paired data, the pre-test and post-test scores with $\mathrm{Z}$ statistical test, in the significance level of $95 \%(\alpha=0.05$, two-party test $)$ with $n=25, Z_{\text {table(1-1/2 } \alpha)}=Z_{0.975}=0.85$. The examination criteria were as follows: $\mathrm{H}_{0}$ was accepted if $-\mathrm{Z}_{\text {table }}<\mathrm{Z}_{\text {count }}<\mathrm{Z}_{\text {table }}$ and unaccepted if other events occurred. As $\mathrm{Z}_{\text {count }}$ $=2.28>Z_{\text {table }}=0.85, \mathrm{H}_{0}$ was unaccepted, confirming that there was a significant difference between the pre-test and post-test about the knowledge aspect.

Evaluation stage was carried out during the trial stage II with results as follows: the minimum and maximum pre-test scores were 29 and 36 respectively, minimum and maximum post-test scores were 30 and 39 respectively, mean and standard deviation of pre-test scores were 31.72 and 1.79 respectively, and that of post-test scores were 35.08 and 2.08 respectively. Next, the $Z$ statistical test was done in the significance level of $95 \%(\alpha=0.05$, two-

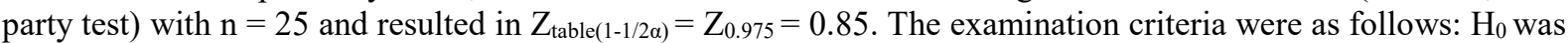
accepted if $-Z_{\text {table }}<Z_{\text {count }}<Z_{\text {table }}$ and unaccepted if other events occurred. As $Z_{\text {count }}=2.28>Z_{\text {table }}=0.85$, $H_{0}$ was unaccepted, confirming that there was a significant difference between the pre-test and post-test about the knowledge aspect.

Referring to explanation above, the development of local content learning module for karawo embroidery in vocational high schools in Gorontalo had been successfully performed.

\section{Closing}

According to the discussion, we drew several conclusions:

1. Local content learning module for karawo embroidery in vocational high schools in Gorontalo was carried out by applying the research and development approach based on the ADDIE development model consisting of: 1) Analyze, 2) Design, 3) Develop, 4) Implement, and 5) Evaluate.

2. Means of module validation by material experts, media expert, teacher, and students were 94.99 (very valid), 90.37 (very valid), 96.43 (very valid), and 92 (very valid) respectively.

3. After the local content learning module for karawo embroidery was given to students of high vocational schools in Gorontalo, their learning output had significantly increased, conveyed by $\mathrm{Z}$ score of $2.28>\mathrm{Z}_{\mathrm{table}}=$ 
0.85 .

\section{REFERENCES}

Ministry of National Education. 2008. Pengembangan Bahan Ajar dan Media. Jakarta: Ministry of National Education.

Husain, Sapia. 2009. Kurikulum Karawo. Gorontalo.

Riyanti, A. 2003. Upaya Penumbuhan Wirausaha Baru. Journal. Infokop Number 29 Year XXII, 2006. Jakarta. Sembel, Roy. 2007. Apakah Anda Memiliki Jiwa Wirausaha? (www.roy-sembel.com, Sandra Sembel, pemerhati dan praktisi pengembangan SDM sembel@yahoo.com.2007. Accessed on January 23 $3^{\text {rd }}, 2019$ at 9 p.m.

Sugiyono. 2010. Metode Penelitian Pendidikan Pendekatan Kuantitatif, Kualitatif, dan R\&D. Bandung: Alfabeta.

Sumarno, Alim. 2012. Penelitian Kausalitas Komparatif. Surabaya: E-learning UNESA.

Suryana, 2006. Kewirausahaan, Pedoman Praktis: Kiat dan Proses Menuju Sukses, Salemba Empat.

Wiryokusumo, Iskandar. 2011. Dasar-dasar Pengembangan Kurikulum. Jakarta: Bumi Aksara. 